\title{
MAJA BITENC: Z JEZIKOM NA POTI MED IDRIJSKIM IN LJUBLJANO
}

\section{Vojko GORJANC}

Filozofska fakulteta Univerze v Ljubljani

Gorjanc, V. (2016): Maja Bitenc: Z jezikom na poti med Idrijskim in Ljubljano. Slovenščina 2.o, 4 (1): $118-123$.

DOI: http://dx.doi.org/10.4312/slo2.0.2016.1.118-123.

Monografija Maje Bitenc, ki je letos na začetku poletja izšla pri Znanstveni založbi Filozofske fakultete, je nastala na podlagi avtoričine doktorske raziskve. Pričujoča sociolingvistična študija je v zadnjem času eno najbolj svežih slovenističnih jezikoslovnih del pri nas, vsebinsko in metodološko pa aktualna tudi v mednarodnem prostoru.

$\mathrm{V}$ prvem delu monografije avtorica svoje delo umesti najprej $\mathrm{v}$ širši sociolingvistični okvir, v nadaljevanju pa v okvir variantnostne sociolingvistike. Ta se je oblikovala kot eno od področij sociolingvistike že zelo zgodaj, v šestdesetih letih prejšnjega stoletja, in sicer primarno $\mathrm{s}$ preorientacijo zanimanja zahodne dialektologije, ki takrat iz ruralnih jezikovnih variant preusmeri svoj fokus v urbana okolja (Labov 1966). Danes velja za eno od osrednjih področij sociolingvistike, ${ }^{1}$ usmerjeno v opazovanje in interpretacijo variabilnih pojavov, in sicer v povezavi med jezikom in družbo, pri čemer je v svojih interpretacijah močna tako pri predstavitvah jezikovnih variabel, torej jezikovne strukture in pomena, kot tudi družbenih dejavnikov, ki vplivajo na jezikovno rabo (Tagliamonte 2006). Variantnostna sociolingvistika kot

\footnotetext{
${ }^{1} \mathrm{Na}$ letošnjem Sociolingvističnem simpoziju, osrednjem znanstvenem srečanju s področja sociolingvistike, ki poteka že od leta 1976 in se ga je v Murcii udeležilo več kot 1000 raziskovalcev s približno toliko predstavitvami, je bilo področje variantnostne sociolingvistike glede na število prispevkov za področjem sociologije jezika drugo najbolj zastopano raziskovalno področje sociolingističnih raziskav: http://www.um.es/web/sociolinguisticssymposium21/participation-statistics (28. 6. 2016).
} 
osrednji teoretsko-metodološki okvir raziskave se pri Maji Bitenc dopolnjuje z raziskovanjem sociopsiholoških dejavnikov (jezikovna stališča, jezikovna identiteta, prestiž, ozaveščenost), teorijo govornega prilagajanja, zaznavno dialektologijo, antropološko lingvistiko in kritično analizo diskurza. Gre za področja sociolingvistike, ki so med najbolj aktualnimi sociolingvističnimi pristopi oz. tudi področja, ki so se oblikovala kot samostojna raziskovalna področja na podlagi kritike sociolingvistike, kot je kritična analiza diskurza.

Eden od vidikov opazovanja je torej tudi kritična analiza diskurza, ki pa je v avtoričinem pristopu programsko pomožni raziskovalni koncept. V prihodnje bi obstoječe gradivo lahko interpretirali tudi z izhodiščem v kritični analizi diskurza, vrsti diskurzne analize, pri kateri bi nas prvenstveno zanimala razmerja družbene moči, neenakost $\mathrm{v}$ diskurzu, tudi zloraba družbene moči. Analiza, ki se osredotoča na stanje in postopke vzpostavljanja družbene moči, njenega ohranjanja in reproduciranja (Dijk 2001), ter raziskava vloge diskurza pri vzpostavljanju neenakosti v družbi v procesu dominacije (Fairclough 2001) bi lahko razkrila, npr. kako na jezikovno obnašanje vpliva porazdelitev institucionalizirane družbene moči (npr. šola, javne institucije), kot tudi okoliščine, ki jih govorci percipirajo in interpretirajo s stališča družbene moči in njihovega vpliva na jezikovno obnašanje (npr. politični in ekonomski centri moči), prav tako pa tudi v večji meri razkrila ideologije, ki se oblikujejo in utrjujejo $\mathrm{z}$ jezikovno rabo ter $\mathrm{z}$ rabo jezika vzpostavljajo družbeno hierarhizacijo.

Raziskava se umešča $\mathrm{v}$ sklop sorodnih raziskav $\mathrm{v}$ tujini, ki jih avtorica $\mathrm{v}$ monografiji tudi na kratko predstavi: o Norvežanih s podeželja $\mathrm{v}$ Oslu, Moravcih v Pragi, Kanadčanih v Veliki Britaniji in Alabami, pa tudi o jezikovnem obnašanju v skupnostih na nemškem podeželju in spremembah v realnem času pri mobilnih in nemobilnih osebah na Danskem (Bitenc 2016: 83-96). Natančen pregled v sorodne raziskave in njihovo kritično vrednotenje ji omogočata oblikovanje namena in cilja njene raziskave ter oblikovanje koherentnega metodološkega aparata. 
Raziskavo odlikuje - kar velja za variantnostno sociolingvistiko sploh - prav empirični pristop in zanesljiva metodologija ter jasna osnovna hipoteza. Avtorica izhaja iz predpostavke, »da so jezikovni repertoarji in strategije govornega obnašanja pri (geografsko mobilnih) posameznikih različni in da gre pri tem za kontinuum, razpet med pogosto idealizirana pola knjižnega jezika in narečja « (Bitenc 2016: 171). V izhodišču pristopa je razmislek o informantih, jezikovnih variablah, transkripciji govornega korpusa in distribucijski analizi variabel. Avtoričina raziskava je $\mathrm{v}$ okviru variantnostne sociolingvistike metodološko inovativna predvsem zaradi uporabe celodnevnega avdio snemanja informantov, s čimer je bilo pridobljenega izjemno veliko relevantnega gradiva za analizo jezikovnega obnašanja glede na okoliščine različnih govornih dogodkov. Kot dopolnilo osnovne variantnostne študije so bili uporabljeni še sociolingvistični intervjuji, predvsem za osvetljevanje razumevanja jezikovnih izbir informantov in proučevanja njihovih jezikovnih stališč (Bitenc 2016: 257). Čeprav so govorci z Idrijskega za avtoričino študijo izbrani, ker tudi avtorica sama izhaja iz tega okolja, pa bi za prvo tovrstno analizo pri nas najbrž težko izbrali boljše izhodišče: gre namreč za dnevno mobilne informante iz okolja, $\mathrm{v}$ katerem je regionalna jezikovna identiteta izjemno močna, njihovo govorno prilagajanje pa vplivano tudi s (skritim) prestižem dialekta, kar je $\mathrm{v}$ dominantno standardnojezikovni kulturi pomemben faktor govornega prilagajanja.

$\mathrm{Z}$ jasnim metodološkim pristopom se raziskava umešča $\mathrm{v}$ aktualno sociolingvistiko, ki jo glede na sklepno plenarno diskusijo na letošnjem Sociolingvističnem simpoziju odlikuje prav metodologija, ${ }^{2}$ včasih tudi na račun manj kritičnih pristopov oz. pristopov s stališča kritične teorije. ${ }^{3}$ Posredno avtoričina raziskava opozarja tudi na težavo jezikoslovnih pristopov, ki so šibki prav v metodologiji oz. celo metodologije ne prepoznavanjo kot ključnega

\footnotetext{
2 https://www.conftool.pro/sociolinguistics-symposium2016/index.php?page=browseSessions\&form_session=351 (28. 6. 2016).

3 Slednje je sicer lahko tudi težava sociolingvistike, saj je v razmerju do drugih kritičnih humanističnih in družboslovnih pristopov manj družbeno angažirana.
} 
elementa jezikoslovnega raziskovanja, $\mathrm{s}$ čimer pravzaprav ostajajo na predznanstveni ravni.

Raziskava razgrne kompleksnost jezikovne rabe dnevno mobilnih oseb $\mathrm{z}$ Idrijskega $\mathrm{v}$ Ljubljano in tudi kompleksnost jezikovnih izbir $\mathrm{v}$ različnih okoliščinah. Pokaže predvsem, da med skrajnima poloma, jezikovnim standardom in dialektom, obstaja izjemna govorna variantnost, oba pola pa sta zgolj dve večinoma idealizirani govorni izbiri. Prav tako se pokaže, da so jezikovne izbire v veliki meri nepredvidljive, saj različne osebe $v$ istih jezikovnih situacijah izbirajo zelo različne jezikovne variante, na izbiro namreč vpliva vrsta osebnih dejavnikov, različnost socializacij posameznikov, s katerimi so zavestno ali podzavestno oblikovali stališče do različnih jezikovnih variant in jezikovnih izbir. Zaradi vsega tega se je pri informantih izkazalo, da uporabljajo zelo različne strategije govornega obnašanja, s čimer se razdelijo v različne tipe govorcev, od tistih samo dialektalnih do tistih, ki preklapljajo kod, ter t. i. kodnih mešalcih. Pri slednjih gre pri vsakem pravzaprav za svoj tip govorca, saj se eni veliko bolj približujejo tipu dialektalnega govorca, drugi pa kodnim preklopljevalcem. Sociolingvistični intervjuji dodatno osvetljujejo kompleksne razloge jezikovnega obnašanja, izkazujejo pa, da so med različnimi dejavniki »najbolj relevantni osebna zgodovina posameznika, njegove osebne lastnosti in jezikovne sposobnosti, družbena mreža, trajanje in narava jezikovnega stika, izkušnje, ki jih ima z jezikovno rabo v različnih okoljih, in z vsem tem povezana jezikovna stališča ter dojemanje povezave med jezikom in identiteto« (Bitenc 2016: 287).

Za zavedanje jezikovne realnosti so rezultati raziskave na osnovi empiričnih podatkov za slovenski prostor izjemnega pomena, saj prikazujejo, kako je jezikovna realnost večinoma med dvema poloma, jezikovnim standardom na eni in dialektom na drugi strani. Ker pa se slovenistično jezikoslovje v veliki meri zanima za opis standarda na eni in dialektov na drugi strani, tako ostaja največji del jezikovne realnosti zunaj zanimanja jezikoslovja. Prav tako se z empiričnimi podatki razkrivajo tudi odnosi do dialekta in drugih jezikovnih 
variant, posredno tudi do standardnojezikovne ideologije. Prav slednje bi na večjem vzorcu lahko prineslo ustrezne podatke za razmislek o vlogi in položaju jezikovnega standarda in razkrivanju prestiža, s čimer bi se oddaljili od posplošenih in z ničimer podprtih izjav o vprašanju jezikovnega prestiža (Tivadar 2012; Tivadar 2015), ki trenutno s pozicije moči služijo zgolj poskusu utrjevanja standardnojezikovne ideologije.

Za slovenski prostor je študija izjemno pomembna tudi za razvoj poststrukturalnega jezikoslovja in s tem jezikoslovja v celoti. Ker velik del evropskega jezikoslovja še vedno temelji na strukturalistični tradiciji, v jezikoslovno raziskovanje pa niso bili vključeni poststrukturalni pristopi, evropska jezikoslovna misel namreč zaostaja za sodobnim humanističnim in družboslovnim raziskovanjem (Motschenbacher 2010: 5), kar velja tudi za velik del slovenističnega jezikoslovja, ki le $\mathrm{s}$ težavo $\mathrm{v}$ svoje raziskave vključuje poststrukturalne jezikoslovne pristope, še težje pa jih povezuje $s$ poststrukturalnimi družboslovnimi raziskavami.

Monografija Maje Bitenc je odlična osnova za načrtovanje sorodnih sociolingvističnih raziskav pri nas; $\mathrm{s}$ tem ko je bila variantnostna sociolingvistika pri avtorici nadgrajena z vrsto drugih, že omenjenih pristopov je namreč že začrtan teoretsko-metodološki okvir za širši sociolingvistični raziskovalni projekt, ki bi lahko s skupnim ciljem in metodološko pestrostjo bistveno pripomogel h kvalitetnemu opisu slovenske jezikovne realnosti.

\section{LITERAT URA}

Bitenc, M. (2016): Z jezikom na poti med Idrijskim in Ljubljano. Ljubljana: Znanstvena založba Filozofske fakultete.

Dijk, T. A. van (2001): Critical discourse analysis. D. Tannen, D. Schiffrin, H. E. Hamilton (ur.): Handbook of Discourse Analysis: 352-371. Oxford: Blackwell.

Fairclough, N. (20012): Language and power. London, New York: Longman. 
Labov, W. (1966): The social stratification of English in New York City. Washington: Center for Applied Linguistics.

Motschenbacher, H. (2010): Language, Gender and Sexual Identity: Poststructuralist Perspectives. Amsterdam, Philadelphia: John Benjamins.

Tagliamonte, S. A. (2006): Analyzing Sociolinguistic Variation. Cambridge: Cambridge University Press.

Tivadar, H. (2012): Nevarna razmerja med pisnim in govorjenim jezikom. N. Jakop in H. Dobrovoljc (ur.): Pravopisna stikanja: Razprave o pravopisnih vprašanjih: 203-211. Ljubljana: Založba ZRC, ZRC SAZU.

Tivadar, H. (2015): Variantnost v prihodnjem slovenskem pravopisu (s poudarkom na pravorečju). H. Dobrovoljc in T. Lengar Verovnik (ur.): Pravopisna razpotja: Razprave o pravopisnih vprašanjih: 109-121. Ljubljana: Založba ZRC, ZRC SAZU.

To delo je ponujeno pod licenco Creative Commons: Priznanje avtorstvaDeljenje pod enakimi pogoji 4.o Mednarodna.

This work is licensed under the Creative Commons Attribution-ShareAlike 4.o International. 